\title{
'Constructing' Ethical Mineral Supply Chains in sub-Saharan Africa: The Case of Malawian Fair Trade Rubies
}

\section{Gavin Hilson}

\begin{abstract}
Over the past decade, sales of Fair Trade agro-products have risen sharply, fuelled by innovative marketing campaigns that use imagery to 'connect' Western consumers to impoverished farmers in developing countries. The success of Fair Trade has led to speculation over whether its portfolio could be broadened to include non-agricultural products, a debate which, in recent years, has focused heavily on the precious minerals and stones being extracted by impoverished artisans. A lack of policy oversight, however, has resulted in Fair Trade being interpreted very differently in this context. In the absence of certified internationally-recognized guidelines to consult for assistance with the implementation of Fair Trade mineral schemes, designers have drawn inspiration from a global mining development agenda that has become heavily preoccupied with anti-corruption and traceability. This paper draws on the case of Malawi's Nyala ${ }^{\mathrm{TM}}$ ruby, described as a 'Fair Trade Gem' by its supplier, to illustrate how ethical mineral programmes are potentially being misbranded as Fair Trade. Although the scheme delivering Nyala ${ }^{\mathrm{TM}}$ ruby to markets is supplying a traceable commodity, in the process helping to alleviate consumers' concerns about conflict minerals, it seems to be providing very little benefit to poor producers - the primary objective of Fair Trade.
\end{abstract}

First unnumbered footnote:

The author would like to thank Mr. Paul Kamlongera for his assistance with fieldwork, and the editors and three anonymous reviewers for their commentary on an earlier draft. Financial support for this research was provided by the British Academy under the project, 'Fair Trade: Challenges and Prospects for Small-Scale Miners' (SG101448). Needless to say, any errors this paper may contain are the sole responsibility of the author. 
'Fairtrade has already come on a breath-taking journey. We've established a proven model for doing business differently, which is already bringing tangible positive impacts for millions of people in farmers' organizations and their wider communities, who have been able to improve their lives, and start to tackle the poverty and disadvantages they face.'.

- $\quad$ Harriet Lamb, CEO Fairtrade International, 2012

\section{INTRODUCTION}

Over the past decade, a number of ethical consumption and production schemes have been launched. The most successful — and which today, are considered the flagship interventions in this area (Bezençon and Blili, 2011) — have been those implemented under the 'umbrella' of Fair Trade, a global campaign which uses imagery and innovative labelling to influence purchasing. The stated raison d'être of Fair Trade is to empower the developing world's smallholder farmers by providing conduits to markets of 'socially and environmentally conscious consumers in the North' (Murray et al., 2006: 180). It is a system which serves as a 'second-best proxy': although 'situated' within a global policy structure that marginalizes small producers and not constituting justice itself, Fair Trade 'offer[s] a form of justice-emulation or justice-promotion in the absence of justice being institutionalized at the global level' (Walton, 2010: 434). It achieves this by 'interven[ing] in the ordering of the matrix of global capitalism whilst [remaining] firmly embedded in it' (Adams and Raisborough, 2008: 1166).

The success Fair Trade has had with bringing to the market a variety of smallholdercultivated goods, including various teas and coffees, cocoa and bananas, has fuelled speculation over whether its portfolio could be broadened to include non-agricultural products. In recent years, this discussion has focused heavily on the precious minerals and

\footnotetext{
${ }^{1}$ http://www.fairtrade.net/single-view+M5e9f4b46d47.html (Accessed 12 July 2013).
} 
stones extracted by artisans, many of whom, much like the smallholders being targeted by national and international Fair Trade organizations, are heavily impoverished and have low market access. With there being a great deal of emotion behind, and thought put into, most jewellery purchases, proponents of Fair Trade see enormous potential with launching schemes which also seek to engage consumers through imagery. As with widely-consumed 'tropical' fruits, the idea being proposed is to 'socially re-embed commodities, so that items arrive at the point of consumption replete with information regarding [the] social and environmental conditions under which they were produced and traded' (Raynolds, 2002: 415). As Goodman (2004: 893) explains, doing so ensures that 'Fair trade's moral economy is written on the commodities trafficked from one part of the globe to another, connecting these places in a novel economy of semiology'.

For the 'tropical' agricultural goods at the heart of the Fair Trade campaign, emphasis has been placed on establishing 'an association with small farmers and families', a strategy which has proved highly effective 'because it evokes populist images of smallholders working on their own land and struggling to remain independent and autonomous, as the market inexorably draws them and their labour into commodity markets' (Luetchford, 2007: 2). These ideas have certainly influenced purchasing by grafting a sizable scar on the consumer's conscience. As demonstrated by a host of studies (e.g. Loureiro and Lotade, 2005: Howard and Allen, 2008), armed with the knowledge that a premium is being used to support the producers they 'see' on packaging, a large share of consumers are now willing to pay slightly more money for Fair Trade products. Many also believe that the groups of farmers supplying the certified products they purchase are guaranteed a floor price when market prices are low; provided with credit to support their activities; and have in place longterm relationships with importers and cooperatives (after Levi and Linton, 2003). Beginning as a grassroots movement in the 1960s, initially popularized by 'alternative trade 
organizations' and surfacing in response to glaring inequalities between developed and developing countries, Fair Trade has rapidly gained momentum over the past two decades (Elder et al., 2012; Raynolds, 2002; Wilson, 2010). During this period, it has evolved 'from an informal network of activists and producers' into a 'structured set of actors whose collective adherence to "fair" principles is guaranteed by external certification programs' (Marston, 2013: 162). In 2011, global sales of Fairtrade International (FLO) goods alone were in the range of US\$ 6.6 billion. $^{2}$

Several early critiques of Fair Trade (see e.g. Levi and Linton, 2003; Young and Utting, 2005) provided reassurance to enthusiastic customers, painting an extremely positive picture of the network. The literature, however, has since taken on a slightly more critical tone in response to a series of questions raised about the true impact of certified products in producer countries (see e.g. Bassett, 2010; Bezençon, 2011). Aside from the obvious criticism of Fair Trade remaining a 'second best proxy' and not seriously challenging the status quo, there have been repeated calls for greater clarification of which producers are, in fact, being targeted and why, as well as what positive change — if any — the movement is bringing to poor farming communities across Latin America, sub-Saharan Africa and Asia. Griffiths (2012: 360) summarizes some of the observations made thus far:

It has been shown that a small amount of the extra amount that consumers pay for Fairtrade gets even as far as the exporter. In a few cases, it may be as much as half; in many cases it is much less. Much of the extra price paid, the donation, goes either in high profit in the rich countries, or in the Fairtrade organisations' administration costs and their cost of collecting donations.

These concerns underscore why a deepened analysis of the nuances of the Fair Trade network, how it operates and where monies are flowing within its structures must take place

\footnotetext{
${ }^{2}$ FLO is the dominant certifier of Fair Trade products. See www.thenews.coop/article/global-fairtrade-certifiedsales-grow-12-66b-2011 (accessed 11 January 2013).
} 
before any consideration be given to broadening the agenda to include a highly-complex sector such as mining. This is important for two reasons, the first being the scale of the challenge. Whilst on the surface, it may appear that the smallholder farmer and the artisanal miner $^{3}$ face similar challenges, in practice, it is very different. Each is confronted with a unique set of circumstances, a direct result of the marked differences in the value of the commodities they produce, the markets they supply and the actors controlling their production chains: unlike diamonds and other gemstones, there is little chance of civil violence erupting over bananas or grapes. The second reason is that, in the absence of detailed information about the organization of precious metals and gemstone production, programmes which target minerals have evolved in a policy 'vacuum'. In the absence of internationally-recognized standards and guidance, a wide range of definitions of 'fair' have gestated and certification schemes have developed rather autonomously. Not surprisingly, few of the programmes that have emerged from this 'vacuum' align with the criteria of Fair Trade accreditation bodies such as FLO-CERT or come remotely close - at least on paper — to mirroring the certification schemes currently in place for 'tropical commodities'.

The purpose of this article is to provide an extended analysis of how Fair Trade mineral schemes are conceived, and to critically reflect on the socio-economic implications of the 'ethical mining' agenda they are shaping. The analysis draws heavily on the case of Malawi's Nyala $^{\mathrm{TM}}$ ruby programme, one of a range of Fair Trade mineral schemes that have been launched over the past decade. The article argues that, in the absence of a blueprint for

\footnotetext{
${ }^{3}$ Artisanal mining is defined here as low-tech, labour-intensive mineral extraction and processing. In sub-Saharan Africa, a large percentage of this activity is undertaken by families and other small groups (colleagues, inhabitants of the same village, extended families, etc.). These producers generally have profit-sharing agreements in place. The region's ASM communities are made up of a diverse range of people, including the 'pit owner' or manager, diggers and washers, and generally lack technological and financial resources. Throughout this article, 'artisanal mining' and 'small-scale mining' are used interchangeably.
} 
Fair Trade minerals, conceivers of such — what are now widely considered to be landmark programmes have drawn inspiration from a mining development policy framework which has become overly preoccupied with transparency and traceability.

\section{ESTABLISHING AND RE-ROUTING THE POLICY AGENDA FOR 'FAIR TRADE' MINERALS}

For a number of Fair Trade 'tropical' commodities, including various teas, coffees and fruit, there seems to be some discrepancy between what consumers believe they are buying and what they are actually purchasing. The gap could be even larger for minerals.

With the images of the general Fair Trade campaign weighing heavily on their consciences, numerous consumers have started calling for jewellery to be manufactured using minerals that have been sourced responsibly. ${ }^{4}$ These consumers have subconsciously fused the positive imagery projected by Fair Trade agro-campaigns with the images of hazardous and at times, exploitative, artisanal precious mineral and stone production. They appear to genuinely believe that purchases of the 'ethical' jewellery they have managed to usher into numerous high street retail shops are helping to alleviate the hardships of numerous subsistence mining groups. Whilst in most cases, there is little reason to believe that minerals are being sourced irresponsibly, with few exceptions, the 'ethical' jewellery being supplied is a significant departure from what consumers have come to recognize 'Fair Trade' to mean. A broadened understanding of the mining 'equivalents' of the farmers being targeted by Fair Trade underscores the magnitude of this disparity.

\footnotetext{
${ }^{4}$ See www.mvimarketing.com/jcoc.php (accessed 12 May 2012) for research conducted by the Jewellery Consumer Opinion Council.
} 
The impression being conveyed by a number of Fair Trade bodies is that certified agro-schemes target marginalized farmers who, in exchange for complying with a range of rather stringent standards, are paid a premium for their produce and connected to international markets. This message is made clear in the mandates of most organizations operating at all levels of the network. The Fair Trade Federation, for example, stresses that 'Fair Trade is a strategy for poverty alleviation and sustainable development', and therefore seeks to "create opportunities for economically and socially marginalized producers'. 5 The Fairtrade ${ }^{\circledR}$ Foundation advocates much of the same, championing Fair Trade as 'a strategy for poverty alleviation and sustainable development', the purpose of which 'is to create opportunities for producers and workers who have been economically disadvantaged or marginalized by the conventional trading system'. ${ }^{6}$ In the mining sector, the most 'economically disadvantaged' and 'socially marginalized' producers are the artisanal operators who struggle to secure licenses, are generally excluded from donor assistance programmes and, unable to access financial support through formal channels, often fall prey to predatory middlemen (Hilson and Pardie, 2006). Over the past two decades, the donor community's approach to regulating and assisting these individuals has been noticeably laissez-faire: a shortage of information on the whereabouts of activities, the demographics of the industry's participants, and their struggles and needs has crippled efforts to formalize operations, and at times spawned highly inappropriate support measures. Organizations with preconceived notions of Fair Trade, therefore, have encountered very little resistance from

\footnotetext{
${ }^{5}$ www.fairtradefederation.org/ht/d/sp/d/sp/i/8447/pid/8447 (accessed 12 April 2012). 6

www.fairtrade.org.uk/what_is_fairtrade/fairtrade_certification_and_the_fairtrade_mark/the_fairtrade_ mark.aspx (accessed 15 April 2012).
} 
donors and policy makers, whose calls for the inclusion of marginalized artisanal miners in national rural development strategies and policies have amounted to little more than rhetoric.

What types of programmes have emerged from this policy 'vacuum'? Three critical reflections are offered here, which not only help to answer this question, but also explain why the agenda for Fair Trade minerals is moving in the direction it is, and ultimately, why schemes such as Nyala ${ }^{\mathrm{TM}}$ ruby are now, rather inexplicably, seen as inspiring interventions in this area. The first point is that few, if any, Fair Trade mineral schemes seem to be zeroing in on the poorest artisanal miners — again, the mining 'equivalents' of the smallholders being targeted by agro-schemes. This comes as no surprise because, as indicated, there is simply no pressure being applied by donors and policy makers to do so, which has enabled individual organizations to arrive at their own definitions of 'fair' and determine who to target on their own. An appropriate definition of 'fair' seems to be an issue which the network's governing bodies themselves have long struggled to identify; the overarching problem is that "unlike many green and organic products, there are no clear standards about what fair trade means' (Hira and Ferrie, 2006: 108). With agro-products, however, there are at least basic principles to fall back on for guidance should schemes show signs of unravelling over polarizing viewpoints on definitions of 'fair'. The same cannot be said for minerals, for which again, there is no consensus on how these principles apply.

The second point is what the Fair Trade minerals manifesto could become in the absence of a robust blueprint: too aligned with a mining development agenda, which, as indicated, has become increasingly preoccupied with transparency, anti-corruption and accountability. Whilst traceability is undoubtedly a crucial aspect of Fair Trade, it is by no means its only component; nor is it its most important strand. In recent years, a number of mineral traceability schemes have emerged, particularly in East Africa. The designs of each are grounded heavily in the framework for a 'responsible global supply chain' presented in 
the OECD's 'Due Diligence Guidance for Responsible Supply Chains of Minerals from Conflict-Affected and High-Risk Areas' (OECD, 2010). This collaborative governmentbacked multi-stakeholder initiative was developed with inputs from the OECD, eleven countries of the International Conference on the Great Lakes Region (Angola, Burundi, Central African Republic, The Republic of Congo, Democratic Republic of Congo, Kenya, Rwanda, Sudan, Tanzania, Uganda and Zambia), ${ }^{7}$ industry partners, civil society and the United Nations. Its aim is to 'cultivate transparent mineral supply chains and sustainable corporate engagement in the mineral sector with a view to enabling countries to benefit from their natural mineral resources and preventing the extraction and trade of minerals from becoming a source of conflict, human rights abuses, and insecurity' (ibid.: 3). The main focus of these initiatives, however, is to provide a "chain of custody tracking from mine to export at country level, regional tracking of mineral flows through the creation of a database on their purchases, independent audits on all actors in the supply chain and a monitoring of the whole mineral chain by a Mineral Chain Auditor' (Bleischwitz et al., 2012: 27). As a result there is, as indicated, a real risk of 'fair' or 'ethical' in this context becoming too strongly associated with 'traceability'. This appears to have already happened with Fairtrade and Fairmined Gold, 'the world's first independent ethical certification system for gold'. ${ }^{8}$ With so few miners being able to comply with the Fairtrade and Fairmined Gold standards (Hilson, 2008), traceability or what is described as a commitment to 'offering the first transparent and traceable supply chain for artisanal and small-scale gold mining' (ARM, 2010: 13), has, almost by default, become the centrepiece of its mandate.

\footnotetext{
${ }^{7}$ The International Conference on the Great Lakes Region was established in 2006 in recognition of the political instability in these countries. As part of its mission to ameliorate and prevent cross-border conflicts amongst this group of nations, it has established a regional certification mechanism for cassiterite, coltan, wolframite and gold.

${ }^{8}$ www.fairtrade.org.uk/gold/ (accessed 15 July 2012).
} 
This leads to the third and final concern: selective empowerment. As Bezençon (2011: 66) explains, this has been 'a general concern about Fair Trade' — that it can be exclusionary because of 'its propensity to generate elite producers...or its inability to integrate many producers'. In many instances, it has been observed that its standards can only be accessed by the resourceful elite, at the same time excluding a much larger group of more needy individuals (Mohan: 2009). The most illustrative example of this in the mining sector is again the Fairtrade and Fairmined Gold standards, the design of which were largely informed by a collection of rather unique operations, including those of Oro Verde, widely heralded as 'the first company to devote itself entirely to the "ethical" production of gold' (Bendell et al., 2009: 13). Born in 1999 through strong alliances between community leaders, the activities of Oro Verde, which are located in the Choco Bioregion of Colombia, employ 'green mining techniques'. ${ }^{9}$ Its achievements in the area of environmental management and as a community-level organization have attracted considerable praise, and culminated in a partnership with a number of bodies to form the Alliance for Responsible Mining (ARM). The extensive campaigning undertaken by ARM catalyzed the design and eventual certification of the Fairtrade and Fairmined Gold standards. Today, Oro Verde and a number of contiguous small-scale gold mining operations in Bolivia (Cotapata Mining Cooperative), Peru (e.g. Communidad Aurifera Relave S.A., MACDESA), Ecuador (Bella Rica) and elsewhere in Colombia (Cumbitara's Small-Scale Mining Association, and Cooperativa Minera de la Llanada ${ }^{10}$ are the principal suppliers of Fairtrade and Fairmined Gold.

\footnotetext{
9 'Green mining techniques' in this context are those which do not feat toxic additives such as cyanide and mercury. Oro Verde's 'green' processes feature an array of hand implements and small machines, including panning trays and motorized water pumps. See www.greengoldoroverde.org/ingles/ov mineria_ing.html (accessed 3 January 2013) for the full details of its 'green mining techniques'.

${ }^{10}$ www.communitymining.org/index.php/en/our-initiative (accessed 13 February 2012).
} 
But whilst there is little disputing their 'grassroots' nature, these organizations were by no means impoverished; nor has certification of their gold effected much of a change in operation or tackled the type of local-level hardship Fair Trade bodies claim to be alleviating. Each cooperative was fully-functional and profitable long before ARM's formation in 2004 (e.g., Communidad Aurifera Relave S.A., 1993; Bella Rica Cooperative, 1993; MACDESA, 1997; and Oro Verde, 1999), and is able to use 'green mining methods' because of unique local geological characteristics. The connection to the Western jewellery market provided by certification has simply enriched these relatively-affluent cooperatives even further by bolstering their sales. Most importantly, championing the practices of these mines as a Fair Trade 'standard' could prove detrimental to the artisanal gold mining industry, particularly operations in sub-Saharan Africa: whilst 'the introduction of Fairtrade and Fairmined certification' may, indeed, offer 'new hope' as is claimed, without any assistance, it is impossible for this group of miners to change their practices so they can meet the requirements of the standard ${ }^{11}$ because of the widespread poverty, geological constraints, logistical challenges and capital shortages they face. Collectively, these factors force the majority of the region's artisanal miners to work illegally and in deplorable conditions. It is against this background that Hilson (2008) called for a radical 're-conceptualization' and overhaul of these largely-exclusionary standards for implementation in sub-Saharan Africa. If left unchanged, the initiative will likely continue to nourish mainly an enclave of 'elite' operators. $^{12}$

\footnotetext{
${ }^{11}$ See www.solidaridadnetwork.org/blog/child-labour-artisanal-gold-mines-mali-report-nbc-reporterrichard-engel (accessed 24 May 2012).

${ }^{12}$ Despite these concerns, support for Fairtrade and Fairmined Gold programmes has been initiated in Ghana, Kenya, Uganda and Tanzania, with the support of Solidaridad, the Dutch-based development agency. Solidaridad, ARM and Fairtrade Africa are currently working to "certify small-scale gold miners in Kenya, Uganda and Tanzania' — specifically, eight mining organisations across the three countries. It is unclear which groups of miners are being target or if the concerns raised here are being
} 
In summary, a host of Fair Trade and ethical mineral schemes have emerged over the past decade (see Table 1 for a summary of selected initiatives). ${ }^{13}$ Few, however, align with the central objectives of Fair Trade itself. A lack of consensus over what constitutes 'fair' in the context of mining, as well as a generally low level of familiarity with the dynamics of artisanal mineral production, has created a significant policy 'vacuum', a sizable space in which organizations have been free to design and launch their own programmes, often with very little guidance and pressure from donors and policy makers. The next section of the article elaborates on this discussion by examining the case of Nyala ${ }^{\mathrm{TM}}$ ruby, which has been labelled a 'Fair Trade Gem' by its supplier. The case illustrates how the Fair Trade mineral schemes that have emerged from this policy 'vacuum' have come to fruition, and, drawing on the perspectives of a range of stakeholders, the debates they are fuelling.

In line with the concerns raised in this section of the article, the $\mathrm{Nyala}^{\mathrm{TM}}$ ruby programme has sparked discussion among different actors on what constitutes 'fair'. It seems that its main goal is to provide traceable production. Moreover, through this programme, an elite producer, not poor artisanal operators, is supplying retailers through Columbia Gem House Inc. The latter is a vertically-integrated gemstone mining, cutting and marketing company headquartered in Washington State, and the world's largest supplier of brand-name exotic gemstones. Columbia Gem House has in place an exclusive agreement with the ownership of the Chimwadzulu Mine in Southern Malawi to supply its Nyala ${ }^{\mathrm{TM}}$ ruby line. Whilst this agreement has no doubt delivered some economic benefits to Malawi, findings

addressed comprehensively. See http://www.fairtradeafrica.net/networks-and-partners/gold-network/ (accessed 12 January 2013) and http://www.triplepundit.com/2012/05/dutch-organization-make-fairtrade-gold-standard/ (accessed 8 January 2013).

${ }^{13}$ On 21 July 2010 the Dodd-Frank Wall Street Reform and Consumer Protection Act ('Dodd-Frank Act') was passed. It requires companies to declare whether the coltan, cassiterite, gold or wolframite originated from the Democratic Republic of Congo or adjoining country and, if so, to report on due diligence undertaken on the chain of custody. 
from research carried out in-country and the jewellery community suggest that the labelling of Nyala ${ }^{\mathrm{TM}}$ ruby as a 'Fair Trade Gem' is an exaggeration, and a move that could be easily misconstrued as disingenuous and a marketing ploy, given what consumers have come to understand 'Fair Trade' to mean.

Table 1 here

'CONSTRUCTING' FAIR TRADE MINERAL SCHEMES: THE CASE OF NYALA ${ }^{\text {TM }}$ RUBY

Although no official 'Fair Trade' programme exists for coloured gemstones at this time, a number of dealers and suppliers have championed the importance of ethical frameworks (Shor and Weldon, 2009). Notable among these is the aforementioned Columbia Gem House, which drafted the Quality Assurance and Fair Trade Gems Protocol, a collection of environmental, labour and health and safety standards. As stated on its website, the organization and its jewellery-manufacturing subsidiary, Trigem Designs ${ }^{\mathrm{TM}}$, now offer its consumers 'the option of Fair Trade Gems', which its management maintains are 'closely tracked from mine to market to ensure that every gem has been handled according to these strict protocols' ${ }^{14}$ To ensure adequate supply, it has forged contracts with individual mines across the world, including Chimwadzulu, again, the source of its $\mathrm{Nyala}^{\mathrm{TM}}$ ruby. Doing so has facilitated its transformation into a vertically integrated operation, putting it in a position to cut, polish and treat coloured stones it sources - including Nyala ${ }^{\mathrm{TM}}$ ruby - for retailers. It is one of a number of companies in the coloured gemstone sector that has consolidated its

\footnotetext{
${ }^{14}$ http://www.fairtradegems.com/fair_trade_gems/ (accessed 13 June 2012).
} 
practices in recent years. As Cross et al. (2010: 15) explain, because '[the] industry is highly fragmented at all levels', to avert risk and provide superior product to customers, organizations 'have integrated different sections of the value chain from source to supply'. By consolidating its activities, Columbia Gem House has become one of the largest players in the industry.

In 2003, MINEX, a UK-based company which, at the time, held the mining lease at Chimwadzulu, secured the services of Columbia Gem House to promote its stones. The partnership yielded, inter alia, Nyala ${ }^{\mathrm{TM}}$ ruby, the first collection of which was made available for US retailers in February 2004. These stones are of extremely high quality and therefore, have considerable market potential. Their branding as a 'Fair Trade Gem', however, is cause for concern: Columbia Gem House has likened the potential impact of its Gems Protocol to that of certified agro-schemes. Notably, the organization states on its website that "when conscientious consumers sip their fair trade coffee, the fingers that hold their cups can be adorned with Fair Trade Gems from Columbia Gem House, Inc.' ${ }^{15}$ the implication being that purchases of Nyala ${ }^{\mathrm{TM}}$ ruby are also mobilizing and empowering poor rural masses.

How close has the organization come to emulating certified agro-schemes, and more broadly, what makes Nyala $^{\mathrm{TM}}$ ruby a 'Fair Trade Gem' in the eyes of management? Moreover, what are the views of other key stakeholders on this labelling and the impacts of the scheme in rural Malawi? The analysis that follows critically engages with these questions, drawing upon feedback from semi-structured interviews conducted by the author with key actors in the commodity's supply chain. The research was conducted in two parts. First, semistructured interviews were conducted in Malawi with government officials, small-scale mining representatives and management of the Chimwadzulu mine. These took place in the

\footnotetext{
${ }^{15}$ http://www.columbiagemhouse.com/fairtradegems.html (accessed 14 June 2012).
} 
cities of Lilongwe and Blantyre, as well as in and around the mine site itself. Following transcription and analysis of these interviews, a second round of semi-structured interviews were conducted with the main stakeholders from the retail side, specifically, representatives at Columbia Gem House and its UK distributor, Fairtrade Gemstones (hereafter referred to as the 'Distribution Consortium'), and selected North American-based retailers which stock the stones (See Figure 1 for an overview of the supply chain for $\mathrm{Nyala}^{\mathrm{TM}}$ ruby). From these interviews, it is clear that the Nyala ${ }^{\mathrm{TM}}$ ruby programme is more reminiscent of a basic community development exercise in its embryonic phases than 'Fair Trade'.

Figure 1 here

\section{Imagery for Marketing}

'I have not visited the village...Anyway, I believe...I trust [my supplier]...I believe they are Fair Trade because that is what they tell me'.

- Jeweller, California, USA ${ }^{16}$

Sales of Fair Trade 'tropical' products have risen sharply in recent years in large part because of the success organizations have had with influencing purchasing patterns. As indicated, they have achieved this through innovative marketing campaigns which make extensive use of imagery of impoverished Third World producers, who are often depicted on packaging as operating in hazardous and/or exploitative conditions. These images have weighed heavily on the consciences of consumers.

\footnotetext{
${ }^{16}$ Interview, jeweler, 30/08/11
} 
Many retailers believe that jewellery purchases could also be influenced using similar methods. There is growing consensus that immediate change could be facilitated in the supply chains of coloured gemstones such as ruby, which many consumers have come to understand have traditionally been sourced unethically. The potential for change is perhaps greatest in the United States, which, at present, accounts for 35 per cent of global retail sales of coloured gemstones, a position of dominance it has occupied for several decades (Shor and Weldon, 2010). There has long been widespread speculation about precious stones (emeralds, rubies and sapphires) being used by host governments to finance the purchasing of arms and munitions, and more recently, about gems such as tanzanite supporting terrorist groups such as Al-Qaeda (see Schroeder, 2010). Consumers are now well-informed about these issues; and, more generally, about how the informal, scattered nature of coloured gemstone production has given rise to an environment conducive to unregulated transactions (Cross et al., 2010; Schroeder, 2010).

The main concern in the case of rubies is the political situation in Burma, which has traditionally provided close to 90 per cent of the world's supply of rough. The country has a lengthy history of human rights abuses. In an attempt to deny Burma's military junta, which has a controlling stake in official gemstone extraction activities and exports, mineral revenues, the US Congress and European Union have passed legislation banning imports of rubies mined in the country (Shor and Weldon, 2009). ${ }^{17}$ The sanctions imposed on Burma, combined with illicit smuggling in Madagascar, another important source of gemstones, has

\footnotetext{
${ }^{17}$ In 2003, the Burmese Freedom and Democracy Act was passed, which banned trade (in the US) with Myanmar. But more comprehensive legislation was implemented in 2008 in the form of the Tom Lantos Block Burmese Act of 2008, which specifies that any ruby or jadeite mined in Myanmar cannot be imported into the US for commercial purposes. The move was deemed necessary since a significant share of Burmese gemstones are cut and sold in neighbouring Thailand. The European Union also implemented a series of complementary economic sanctions, including an embargo on the importation of gems sourced from Myanmar.
} 
created a worldwide shortage in supplies of ruby and sapphire in recent years, leaving retailers scrambling to identify alternative sources. It is against the background of these circumstances that Malawi has emerged as a potentially strategic player for gemstones, particularly ruby. This was acknowledged by one manager of the Distribution Consortium during a personal communication:

I know Madagascar production reasonably well. I also was very unhappy about the military junta in Burma back in the late 1990s and went to look for other ruby sources. That led me to the Malawi ruby project, long before the Burma sanctions were put into effect in the US...

The 'Malawi ruby project' referred to here is Chimwadzulu which, despite having a low profile and at times, an unreliable supply, has been in production for over fifty years. During an interview with an officer from the Gemstone Association of Malawi, ${ }^{18}$ it was explained that a South African entrepreneur, Lawrence 'Larry' Hood, secured a mine exploration license in 1994 and, along with recruited UK partners, formed Minex. It was further explained that, 'after operating for nearly twelve years, Minex was put on the stock exchange in London, where it was sold to an Australian man, popularly known as "Mr. Kennedy", for UK£ 200,000'. The company, which has since changed its name to Nyala Mines Limited, currently holds a mining license at Chimwadzulu. It is with this company that Columbia Gem House forged an agreement for purchasing supplies of rough ruby.

Bans on imports of Burmese stones have limited the manoeuvrability of retailers, forcing many consumers to 'settle' for alternatives to ruby, including various garnets and spinel. One jeweller confirmed this in an interview, explaining that '[the ban] is affecting our supply...it has changed the immediate gratification and delivery of product, though people are generally supportive of the situation'. The political situations in both Burma and Madagascar have fuelled a strategic search for alternative supplies of ruby which is why, for

${ }^{18}$ The official 'mouthpiece' and administrative body for small-scale gemstone mining in Malawi. 
the jewellers consulted, Chimwadzulu has such enormous appeal: all see the agreement forged between Columbia Gem House and the Malawian Government as a 'win-win' for each of the parties involved. First, and perhaps most importantly, there is the issue of the quality of Chimwadzulu's rubies. One jeweller described them in an interview as 'spectacular looking stones'. The consensus among the retailers consulted was that superior quality makes Malawi's rubies so attractive; they are, as the same jeweller put it, 'completely natural and untreated gems'. The fact that the stones are, in the words of another jeweller, 'not doctored up before we get it', provides the retailer with an advantage because 'we [are able to] build a story around the fineness of the stone and the rarity, and create a bit more pride and ownership, to indicate how rare and special these particular gemstones are'.

Second, in sourcing these 'completely natural and untreated gems', retailers believe they are genuinely having a positive impact on poor peoples' lives in a democratic — albeit impoverished - developing country removed from the shackles of dictatorship. One retailer made this clear during an interview, a view echoed by all of the retailers consulted. The jeweller stated: 'my impression is that by dealing directly with the people, they are helping to support the economy directly, and making sure that things are done in a fair and equitable way for everyone involved in the process, so that it will be something that builds a longerterm relationship for the people, and that the economy is supported by a consistent relationship'. On its numerous websites, the Distribution Consortium has skilfully used imagery, similar to the way in which Fair Trade bodies mobilize consumers through pictures on the packaging of agro-products, to impress upon retailers that the acquisition of rubies from Chimwadzulu delivers a multitude of benefits to Malawi's poor. One jeweller reflected on this in an interview, explaining that, 'they [the Distribution Consortium] showed pictures, and they showed that...you see their [Malawians] faces in the picture and they were happy, they had a school, they had healthcare'. 
In line with arguments raised earlier about imagery being the centrepiece of Fair Trade marketing strategy, it is evident that pictures and accompanying text which suggest that production at Chimwadzulu is 'improving quality and lives', and is carried out whilst 'protecting the environment' and 'protecting worker's rights', ${ }^{19}$ have engaged the jewellery community. At the time of this research, none of the retailers interviewed had visited Chimwadzulu or seemed to understand the mine's production dynamics. But all were clearly enamoured by the messages espoused by the Distribution Consortium and more generally, the idea of it being able to supply 'Fair Trade Gems'. The sense of belief now resonating in the jewellery community about the local-level impacts of 'Fair Trade Gems' such as Nyala ${ }^{\mathrm{TM}}$ ruby reinforces points raised by Mohan (2009) on the issue of trust. Specifically, the idea that because "fairness" is not an attribute that consumers can check in the product as, aside from the label, Fair trade products are not distinguishable from conventional products', organizations work on 'encouraging consumers to base decisions on trust and charity rather than solely on market competition' (ibid.: 25).

The growing popularity of Nyala ${ }^{\mathrm{TM}}$ ruby among US retailers is a sign of their trust in the Distribution Consortium to deliver on its promise of supplying 'Fair Trade Gems'. All of the jewellers consulted emphasized, during interviews, the importance of trust, particularly when sourcing commodities known to be associated with widespread human rights abuses, such as rubies. This trust, explained one California-based jeweller, needs to exist throughout the supply chain:

I mean, what is the documentation going to be? Honestly, for me, if somebody came to me and said 'look, here are the pictures, these are the miners, these are the living conditions', I would need to really trust that person if he didn't have the documentation. My customer would buy it because they trust me. ${ }^{20}$

\footnotetext{
${ }^{19}$ See http://www.trigemdesigns.com/home/ (accessed 15 June 2012).

${ }^{20}$ Interview, jeweler, 15/09/11
} 
Another jeweller echoed these sentiments, explaining that a major reason why a growing number of retailers 'trust' the Nyala ${ }^{\mathrm{TM}}$ ruby brand is because 'the supplier goes there directly and deals with the people on the ground who are involved in the mining'.

But what exactly does the jewellery community perceive 'fair' to mean in this context? Moreover, given the poor knowledge of the situation on the ground, in committing to purchasing gems such as Nyala ${ }^{\mathrm{TM}}$ ruby, what impact do they believe sales of these stones are having on livelihoods in rural Malawi? The next section of the paper seeks to answer these questions.

\section{Re-conceptualizing 'Fair'}

'When we use rubies, we use Nyala ${ }^{T M}$ ruby because they are traceable'. ${ }^{21}$

- Jeweller, Washington State, USA

It was argued earlier that many of the organizations which have developed ethical mineral supply chains have emphasized heavily the issue of traceability. What makes the case of Nyala $^{\mathrm{TM}}$ ruby slightly unique in this regard, however, is that both the supplier and the retail community have been complicit in developing a working definition of Fair Trade that is far removed from those which underpin the movement itself.

Despite making numerous references to poverty alleviation in rural Malawi and the need for mining to be carried out in a fashion that yields development, all of the jewellers interviewed seemed heavily preoccupied with the issue of traceability. One jeweller pointed

\footnotetext{
${ }^{21}$ Interview, jeweler, 06/09/11
} 
out in an interview that knowledge of a stone's origin 'makes good business sense' because 'the jewellery industry has been an emotional industry, celebrating the most important events in our life - marriage, christenings, anniversaries — and when people find out that this jewellery was derived from suffering, they don't want that'. With the events in Burma and to a lesser extent, Madagascar, looming heavily on the consciences of consumers, it was explained that retailers have been pressured to provide details about the origin of supplies of rough rubies, which has affected the sourcing strategies for all gems. This was made clear in an interview with another jeweller:

We have tried to seek out suppliers and manufacturers who can verify the sources of their products for us, in order to give our customers a better sense of what they are buying, to give them a better sense that it is not conflictual where it is coming from. Whether a diamond from Botswana or tanzanite from Tanzania... The best company we deal with on that is [the Distribution Consortium] — they do a great job with sourcing and helping you to present the products than a number of suppliers we have dealt with for years. They go direct to the source to procure the gemstones, to ensure that they are ethically sourced. ${ }^{22}$

To its credit, the Distribution Consortium is satisfying retailers' growing demands for transparency by supplying $\mathrm{Nyala}^{\mathrm{TM}}$ ruby, a traceable gemstone. As one senior manager explained in an interview, 'a company such as ours must create a transparency to their supply chain [because] only then can they identify positive actions and negative actions along the chain [and] only in this manner can they begin to develop solutions to the negative aspects'. Two of Columbia Gem House's five Quality Assurance and Fair Trade Protocols (Principle 1. 'Demonstrate to the customer where the gemstone they purchased originated', and Principle 4. 'Confirm that obtaining the stone was done legally') focus on the issue of

\footnotetext{
${ }^{22}$ Interview, jeweler, 18/08/11.
} 
traceability, underscoring the organization's commitment to 'Making the Supply Chain Transparent'. ${ }^{23}$

The main reason why these stones are being sourced altogether was made clear during interviews: their economic value. The attraction with Nyala ${ }^{\mathrm{TM}}$ ruby specifically is, as one jeweller clarified in an interview, 'that it is not treated'. For centuries, several treatments coatings, the application of oils and more recently, high-temperature, atmosphere-controlled heating — have been used to alter the appearance, and therefore the perceived value, of rubies (Shor and Weldon, 2009). The jeweller further explained that because no treatment is required in the case of Chimwadzulu's rubies, '[it] makes it rarer [- that] you cannot offer your customer that level of authenticity with an Asian ruby'. All of the other jewellers consulted echoed this view. One explained that 'the nature of the quality of the material being not treated is real special, as opposed to most everyplace else, where it is heat treated', whilst another indicated that 'the untreated aspect, the beauty of them...is cool'. Fully aware of jewellers' desire to secure untreated corundum, the Distribution Consortium has raised awareness of the purity of Nyala ${ }^{\mathrm{TM}}$ ruby. A senior-level employee explained why:

We believe the consumer is an integral part of a Fair Trade supply chain. The industry must be fair to them also and doing all sorts of disclosed and to not disclose (but never explained) treatments was just tricking the consumer. By working directly with the Nyala mine, we could control and clearly describe any treatments and their impact on rarity and value. $^{24}$

The premium placed by retailers on 'natural stones' could explain why two of the remaining three Quality Assurance and Fair Trade Protocols (Principle 2. 'Identify what treatments have been done to the stone, if any' and Principle 3. 'Determine that the stone is of natural origin and not synthetic or imitation') focus on the issue of treatment.

\footnotetext{
${ }^{23}$ http://www.fairtradegems.com/fair trade gems/fair trade gems supply chain.php (accessed 15 May 2012).

${ }^{24}$ Personal communication, officer, Distribution Consortium, 17/08/11.
} 
A preoccupation with transparency and the allure of the gems themselves, however, have overshadowed other - more significant — producer-side aspects of the Fair Trade issue. Despite claims made by jewellers that 'miners are fair waged' and 'the information we have gotten from them [Chimwadzulu's managers] is that they have set up a healthcare facility and a school for the miners and their families', and similar statements made by the Distribution Consortium itself, the 'Fair Trade' ruby programme now in place in Malawi appears to have facilitated little change on the ground. It seems that rather than identifying a marginalized group of producers and developing a scheme to empower them, in this particular case, a positive story was 'constructed' only after a viable deposit of a coveted gemstone was identified in a country free of autocratic rule and where product can be traced to its origin with relative ease.

Residents have clearly grown frustrated over what they see as Chimwadzulu's continued lack of economic impact. This was made clear in an interview with a government officer, who explained that 'although the mine has switched several hands over the years, the major issue of contention has been that people say they don't see the exports and the value the mine brings to the community around the area'. Community development would become the centrepiece of the agreement forged between Nyala Mines Limited and the Government of Malawi on 20 October 2007 - which culminated in a ten-year mining license (ML0150/2007) — and the 'Fair Trade' scheme it would spawn. Enshrined in the agreement are a number of macroeconomic commitments, as well as scores of pledges to improve the social conditions around Chimwadzulu, which managers have packaged as 'Fair Trade': refurbishing the local hospital at Katsekela, and providing it, annually, with at least US\$ 20,000 in medical supplies; installing a solar panel at the hospital to provide lighting; refurbishing and continuing to support a local school; employing locals to work at the mine; and training Malawians in various aspects of the gemstone trade. Presently, Chimwadzulu 
and surrounding communities are in a deteriorated state, largely because of the lengthy struggle to find a buyer for the mine and consequent fluctuations in production. A member of the Distribution Consortium's mine management team at Chimwadzulu conceded having 'inherited a blueprint which has not fulfilled the agreement [with the government]' because of declining output. The recent US\$ 2 million investment in equipment and production facilities, however, is expected to increase output to 30-50 tonnes/day. It has left the same mine manager feeling optimistic about hitherto abandoned plans to support the community. The manager claimed in an interview of 'having adopted this village' and expressing a desire to 'want to do something for these people', including 'building a health centre as well as refurbish the existing Katsekela Health Centre'.

For each of the retailers interviewed, traceability, not the development that their purchases potentially facilitated, was identified as the most important issue. Most, however, praised the development taking place at Chimwadzulu, although none seemed to have a detailed understanding of what type of work is being undertaken. Why, then, is the Nyala ${ }^{\mathrm{TM}}$ ruby scheme being championed as a 'Fair Trade' intervention? Part of the problem could stem from the literature, which regularly uses the terms Corporate Social Responsibility (CSR) and Fair Trade interchangeably. It could, therefore, be the case that the Distribution Consortium views CSR as 'Fair Trade', despite the fact that it is the opposite — that 'Fair Trade', albeit only in particularly instances, could be a form of CSR (after Mohan, 2009). Drawing upon experiences for the cocoa sector, Chavaz (2008: 2) articulates the differences between the two concepts, reporting that 'FT and CSR diverge...in how they address the vulnerability of cocoa farmers, in their response to the prevailing governance of the value chain, and in the level of consumers' involvement they require'. As the author further clarifies, CSR emphasizes the delivery of social benefits to disadvantaged producers, and can only be considered Fair Trade if the measures being implemented challenge the "conventional 
value chain'. Referring back to $\mathrm{Nyala}^{\mathrm{TM}}$ ruby, the pledges enshrined in the agreement forged between the Distribution Consortium and the Malawian Government, as well as the Quality Assurance and Fair Trade Protocols themselves, cannot be considered cornerstones of any Fair Trade programme, at least not in the conventional sense. This is because whilst plans to build a school and supply a health clinic at Chimwadzulu will no doubt deliver meaningful development to surrounding subsistence communities, they will not empower marginalized operators.

Another potential source of the problem in this particular case relates to how the Distribution Consortium is marketing 'Fair Trade Gems' through its supply platform. This has undoubtedly confused many retailers. The Distribution Consortium has skilfully engaged buyers by associating its efforts with those being undertaken to certify agro-schemes, particularly coffee:

Our Fair Trade Gems programme is part of a larger movement of companies in many industries who promote ethical practices toward employees and the environment. The ideas and principles behind Fair Trade have been gathering more and more support among consumers and businesses. Coffee is the most widely available Fair Trade product, with over 100 roasters offering Fair Trade-certified coffee. ${ }^{25}$

The passage is highly misrepresentative, as it implies that schemes such as $\mathrm{Nyala}^{\mathrm{TM}}$ ruby mirror the Fair Trade schemes in place for products such as coffee, which is far from being the case.

For the programme in place at Chimwadzulu to be in any way complementary to the Fair Trade schemes instituted for smallholder farmers, it would, as explained earlier, need to target impoverished small-scale operators, a group which, in Malawi, numbers in the tens of thousands (Kamlongera, 2011). But as the discussion that follows explains, management at all levels of the Distribution Consortium and many of the retailers it supplies are reluctant to

\footnotetext{
${ }^{25}$ http://www.fairtradegems.com/fair_trade_facts/index.php (Accessed 2 May 2012).
} 
embrace the needs of small operators. Ideologically, this runs counter to the objectives of Fair Trade.

\section{Omission of the Small Operator}

'I have as I said adopted this village and I want to do something for these people... We are giving children footballs right now...'

- Mine manager, Chimwadzulu, Malawi

In its various guises, Fair Trade has been marketed as a vehicle which empowers scores of poor producers. In exchange for complying with a set of standards, individuals are connected to consumers, protected from market irregularities and paid a premium for their produce. But as indicated, these guidelines are, at times, stringent, and can be more exclusionary than inclusive, consequently empowering elites. The Chimwadzulu project is no exception.

To its credit, the Distribution Consortium intends on using the Nyala ${ }^{\mathrm{TM}}$ ruby scheme as a foundation for other project-work which, its managers believe, could deliver significant benefits to Malawi if managed effectively. The Distribution Consortium has committed, in the agreement it has forged with the government, to establishing in the country a subsidiary corporate entity capable of cutting/marketing 'lesser value' corundum that could be marketed and sold locally. This was echoed in a communication with one of the Distribution Consortium's senior managers, who explained that 'we have committed to training local 
people on all aspects of the project and [we have] been working to develop the start of a cutting industry in Malawi'. It is the other aspects of the agreement, however, that are highly contentious and which are, overall, in no way aligned with the principles of Fair Trade.

In addition to there being a 10 per cent royalty payable to the government upon export of rough corundum, it was agreed that Chimwadzulu would have 30 per cent 'indigenous' ownership. Initially, the Gemstone Association of Malawi was approached by the management of Minex and offered 10 per cent of the project's shares but was unable to mobilize the funds. The possibility of involving the association as a minority owner, however, has not been revisited by the Distribution Consortium. A recent World Bank report argues that '[in Malawi,] artisanal and small scale mining (ASM) has potential to grow by increasing output and producing higher value products, especially cut and polished gemstones' (World Bank, 2009: 4). In its attempts to design and implement a 'Fair Trade' structure at Chimwadzulu, the Distribution Consortium has, however, rather curiously, dismissed the needs of the sector's operators entirely. The gemstone sector is often condemned for its highly illicit nature — specifically, for allegedly harbouring scores of middlemen, sponsors, informal traders and service-people (Cross et al., 2010). But most of the efforts undertaken to formalize its activities (in countries such as Zambia, for example) were destined to fail, crippled by a poor understanding of the dynamics and organization of the sector. Malawi's ASM sector also appears to be highly informal, illicit and complex. According to the same World Bank report (World Bank, 2009), country-wide, activities provide direct employment to at least 40,000 people, most of whom operate without a license; occur seasonally as well as surface in a 'rush type' fashion; and extract a diverse range of commodities, including gemstones, aggregates, limestone, sand, ceramic clays and salt. Based on the descriptions provided in this report and elsewhere (e.g. Kamlongera, 2011), 
much like a large share of ASM found across sub-Saharan Africa, Malawi's operations are also poverty-driven, labour-intensive and rudimentary in design.

It was explained in an interview with an executive of the Gemstone Association of Malawi that the stones recovered by the country's artisanal miners are 'sold to anyone Israelis, Germans, Australians, British — who polish their stones at their home countries and sell them at auctions [and] I doubt if they have licenses [to buy], which explains why [so many] people smuggle the stones in most cases'. The problem with this arrangement, explained a mine manager at Chimwadzulu during an interview, is that 'they [the villagers] get nothing on the black market — what a person would get for 10,000 Kwacha they are settling for 1,000 Kwacha on the black market'. The miners, local government officers and association executives consulted were in agreement that the Distribution Consortium could have fixed this problem by altering the dynamics of production to their benefit. The idea presented, though challenging, was to forge direct trade links with Malawi's small-scale gemstone miners through the association, a move which, these local-level actors explained, would bring about positive change in the lives of many thousands of the country's poorest people. It would certainly have more of the look of a grassroots Fair Trade scheme than the existing programme, which again, has prioritized the construction of schools and health facilities and the hiring of a small group of people to work at the mine. But rather than assist small-scale operators, mine management has potentially marginalized them even further. The head of the management team in place at the mine explained in an interview that they have 'fenced off' the 'Larry Hood Area where artisanal works are' — that they will 'focus on pits for a while or the seam because artisanal miners follow the seam'. The move reinforces claims put forward by Cross et al. (2010: 21) that 'they [mining and exploration companies] have been known to "use" artisanal and small-scale miners as unpaid "geologists", launching 
large explorations of mineral deposits wherever there is evidence of small-scale mining activity'.

Whilst all of the individuals interviewed from the Distribution Consortium - from managers at the mine to suppliers - praised the 'Fair Trade' ruby scheme in place at Chimwadzulu, the views solicited from community-level actors were very different. In possession of a mining license at Chimwadzulu up until the early-2000s, Lawrence 'Larry' Hood, as indicated, managed to lure investment from the UK, which catalysed the formation of Minex. The main investor, known locally as 'Dr David', engineered the sale of Minex to 'Mr. Kennedy', the formation of the Distribution Consortium, the drafting of the agreement between the Malawian Government and Columbia Gem House, and the launch of the Nyala $^{\mathrm{TM}}$ ruby scheme. All of the association's executives and small-scale miners interviewed condemned the 'Fair Trade' agreement, questioning the level of benefit it delivers. The reason for the mounting local resistance, explained one executive in an interview, is the collective view of the citizenry that 'Malawi has never benefitted from this mine since 1967, despite having produced all these best rubies in the world'. Another executive member even questioned, in an interview, the 30 per cent 'indigenous' ownership ${ }^{26}$ secured, as required by the agreement:

This mine should go to indigenous Malawians because all of the proceeds will come back to Malawi. He [the manager and 'indigenous' owner] has two passports. It needs to be given to registered Malawian small-scale miners. We are losing millions and millions...We do not need a donor. We [the association] have written a petition to get it back into the hands of indigenous Malawians...'

\footnotetext{
${ }^{26}$ With the Gemstone Association of Malawi unable to mobilize funds to secure a stake in the mine, the Distribution Consortium turned elsewhere. In the end, a group of third generation Indian Malawians secured the required 30 per cent share.
} 
A local government officer interviewed in Blantyre sympathized with these views, explaining that 'the Gemstone Association of Malawi wanted to have the mine [for small-scale miners] because it fetches a lot of money, so there's been a lot of cries from these guys'.

The Distribution Consortium, however, is adamant about not working with the country's ASM operators. One of its high-ranking officials explained why in an interview:

Don't go the artisanal route. Wild and uncontrollable. No reason why they should put the money to buy houses and put nothing back into the community...I am sceptical of running up the Bolivian Andes and the Amazon Jungle and finding a miner and saying 'this is Fair Trade' because it doesn't work.

Consequently, the mine itself has become an enclave, now separated from the surrounding villages which, for decades, have relied upon menial gemstone production for their livelihoods, drawing upon reserves from the 'Larry Hood Area'. The highly-mineralized 'Larry Hood Area' is now heavily policed, protected from what were described as 'encroaching small-scale operators', a mine manager explaining in an interview that 'we [at the mine] are armed to the teeth, and we shoot to kill because I don't tolerate stealing'. The reluctance to work with ASM operators resonates deeply in the Consortium, and extends to even jewellers; most of the retailers consulted were also averse to the idea. One explained that 'the logistics of [doing] this [partnering with small-scale miners]' was a 'big challenge', whilst another indicated that 'there are obstacles' because 'it's a complicated thing to deal with the governments in these countries, to be able to develop the relationships with the producers and find the right person in government, etc.'. In what was one of the most revealing conversations, yet another jeweller explained that because 'Africa is the Wild West...I think this is where you need oversight from First World countries that can pull this 
off', furthermore pointing out that 'that's why I sell the Ekati ${ }^{27}$ diamonds from BHP Billiton, because that's the story I can tell my customers'.

In the case of Nyala ${ }^{\mathrm{TM}}$ ruby, what story is the Distribution Consortium passing along to the jewellers they supply and, by extension, consumers? Reflecting on the scheme's labelling, one jeweller explained in an interview that 'I believe [it is] Fair Trade because...the fact that the people are paid fairly, including women, and that they have a school and health care...That's why I think it's Fair Trade'. The problem, however, is that this is not Fair Trade. In fact, ideologically, the approach being taken at Chimwadzulu seems antithetical to the underlying principles of Fair Trade. The unwillingness of the Distribution Consortium to understand and embrace the struggles of the most impoverished group (resident small-scale gemstone miners) seems counterintuitive, very different from what organizations in the Fair Trade network are trying to achieve — or at least what they claim to be doing — with smallholder farming. Armed with the knowledge that the retailers it supplies approves of the sourcing of rubies from a country such as Malawi, which, unlike Burma, has enjoyed a lengthy period of stability and democratic rule, the Distribution Consortium has skilfully crafted a story around the theme of 'community mining'. In the absence of a blueprint, it, along with other organizations, has freely manoeuvred in a sizable policy 'vacuum', designing and implementing what has amounted to little more than a basic community development exercise, masqueraded as a Fair Trade scheme.

\section{DISCUSSION AND CONCLUSION}

${ }^{27}$ The Ekati Diamond Mine is located in Northwest Canada, in the heart of First Nations territory. 
The case study presented in this paper illustrates how convoluted the issue of Fair Trade minerals can become in the absence of universal guidelines and baseline criteria debated and agreed upon by a diverse group of stakeholders. At first glance, the decision to label $\mathrm{Nyala}^{\mathrm{TM}}$ ruby a 'Fair Trade Gem' seems rather arbitrary since the scheme itself is far removed from being a programme which 'connect[s] disadvantaged producers and consumers, promot[es] fairer trading conditions and empower[s] producers to combat poverty, strengthen[s] their position and tak[ing] more control over their lives'. ${ }^{28}$ The initiative itself was conceived almost entirely outside of the host country, Malawi. The emergence of Nyala ${ }^{\mathrm{TM}}$ ruby and allied schemes, however, can be seen as a direct response to consumers' growing awareness of the human rights abuses associated with many forms of mineral production and their growing demand for more traceable products. Suppliers have met these demands head-on, consolidating activities by forging deals directly with individual mines across the world and in the process, improving the transparency of production. The move aligns perfectly with a mining development agenda that has become heavily preoccupied with anti-corruption and improved transparency in recent years. But groups such as the Distribution Consortium have gone a step further, skilfully crafting stories about community development and erroneously labelling their work 'Fair Trade'.

Should these organizations be blamed for steering the Fair Trade minerals agenda down a radically different path to that of Fair Trade agro-products? On the one hand, organizations are clearly abusing the autonomy they have been afforded, developing schemes in a sizable policy 'vacuum' which are, in no way, calibrated with the central tenets of Fair Trade. Lost in the efforts at Chimwadzulu, and a criticism raised regularly about Fair Trade in general, is the level of impact in the producing country itself. With Nyala ${ }^{\mathrm{TM}}$ ruby, it

${ }^{28}$ www.fairtrade.org.uk/what_is_fairtrade/fairtrade_is_unique.aspx (accessed 15 March 2012). 
became clear, during interviews, that the priority is the customer, not the impoverished Malawians who could be supplying the Distribution Consortium. One of the Distribution Consortium's senior-ranking officials conceded as much in an interview. In fact, it seems that the focal point of the scheme's design was retailers' fixation with what one jeweller described as 'the completely natural and unheated gems', the transformation of Chimwadzulu into an enclave-type project reminiscent of most of the large-scale extractive projects that have emerged across sub-Saharan Africa to date a testament to the level of priority being placed on community development. This was made clear in an interview with another jeweller:

That they are untreated and that they have a nice story. I mean I think the Fair Trade benefit is part of the story. You want to tell a story with your product. And it comes from Malawi. Right there is huge. We know where it comes from. The untreated aspect, the beauty of them, the brand name is cool. It's a little deer, ${ }^{29}$ right? They were untreated and they were sourced...Great story.

The Distribution Consortium's lack of understanding of what Fair Trade constitutes was evident during several interviews. One of the more revealing statements was made by a Trigem Designs ${ }^{\mathrm{TM}}$ employee who, in reference to the President of Columbia Gem House, declared in an interview: 'he invented Fair Trade'.

On the other hand, organizations cannot be blamed entirely for overlooking smallscale miners in Fair Trade programmes because there is no requirement to do so. To date, few economic policies, national development programmes and development interventions implemented in sub-Saharan Africa have targeted ASM. Despite mounting evidence pointing to ASM being an indispensable economic activity in all corners of sub-Saharan Africa (see e.g. Banchirigah, 2008; Maconachie and Binns, 2007; Perks, 2011), it continues to feature peripherally in the region's rural poverty alleviation policies and development programmes. In Malawi itself, whilst the most recent IMF Poverty Reduction Strategy Paper does indicate that 'it [the government] will continue to provide extension services to small-scale miners to

${ }^{29}$ The reference made to a deer here is actually an antelope. Nyala is a Southern African antelope. 
learn value added skills' (IMF, 2007: 33), it offers few details on how this will be achieved. The document, much like the PRSPs of neighbouring countries, has a distinct agricultural 'flavour', championing support for smallholder farming as the key to alleviating rural poverty in Malawi. A re-orientation in approach - one which places greater emphasis on ASM development — promises to be difficult.

The problem is compounded by the region's weak mining policies, which also overlook the importance of small-scale activity. Most rather focus on identifying ways to transform large-scale mining into an export-led industry and attract foreign investment to catalyze its development. Whilst both the Africa Mining Vision and the Extractive Industries Transparency Initiative provide platforms for debate on ASM, it is evident, from the composition of the documentation, that safeguarding the wellbeing of the ASM sector is not a top priority of either. Even the Kimberley Process Certification Scheme (KPCS) ${ }^{30}$ — widely considered to be the landmark intervention in the area of mineral transparency and accountability — fails to empower the ASM operator. Khamis (2007: 4) incorrectly refers to the KPCS as an example of an initiative 'launched on behalf of the development of artisanal and small-scale miners of precious minerals', despite this never being its intended purpose. It was rather launched (in 2003) specifically to improve the traceability of diamonds. In fact, it was not until four years after its launch that the Working Group on Artisanal and Alluvial Production (WGAAP) was established, following recommendations put forward at the Moscow Plenary meeting of the Kimberley Process in 2005. Though championed by some (e.g. Haufler, 2009) as a model for preventing the smuggling of conflict commodities, it remains unclear, even with the WGAAP now in place, what the KPCS is doing to empower the artisanal operators working in 'the alluvial diamond mining areas' the group believes are

\footnotetext{
${ }^{30}$ The Kimberley Process Certification Scheme (KPCS) is a joint government, civil society, and industry initiative aimed at stemming the flow of rough diamonds used to finance wars.
} 
in need of 'effective internal controls' to prevent 'conflict diamonds from entering the legitimate diamond trade'. ${ }^{31}$ The lack of focus on artisanal mining provided the impetus for the Diamond Development Initiative ${ }^{32}$ to draft and launch the Development Diamond Standards ${ }^{\mathrm{TM}}$, a certification system designed to be accessible to independent artisanal small producers, and inclusive rather than exclusive (Smillie, 2012).

Given the orientation of Malawi's national development programmes and the mining policy machinery in place in sub-Saharan Africa, the agreement forged between the Distribution Consortium and the Government of Malawi is in no way inappropriate. But it remains unclear how, given the deliberate omission of the country's impoverished small-scale gemstone miners, it could ever "change unequal relationships between producers and consumers [to] empower producers' (Tallontire, 2002: 13), the stated objective of Fair Trade. The agenda for 'ethical' minerals is nevertheless evolving rapidly. Schemes such as Nyala ${ }^{\mathrm{TM}}$ ruby, however, could steer the agenda down a different path to that of agro-products, the heavy preoccupation with traceability in this case overshadowing some of more important pillars of Fair Trade, in particular, empowerment of the small producer.

\footnotetext{
${ }^{31}$ www.kimberleyprocess.com/ (accessed 12 July 2012).

${ }^{32}$ Established in 2008, the Diamond Development Initiative is an NGO which, alongside government, NGO and industry partners, helps to address, in a comprehensive manner, the many problems facing the artisanal diamond mining sector, and empower its operators. See www.ddiglobal.org (accessed 11 January 2013).
} 


\section{REFERENCES}

Adams, M. and J. Raisborough (2008) 'What Can Sociology Say About Fair Trade? Class, Reflexivity and Ethical Consumption', Sociology 42(6): 1165-82.

Alliance for Responsible Mining (ARM) (2010) 'Fairtrade and Fairmined Gold: Empowering Responsible Artisanal and Small-scale Miners'. Alliance for Responsible Mining, Colombia.

Banchirigah, S.M. (2008) 'Challenges with Eradicating Illegal Mining in Ghana: A Perspective from the Grassroots', Resources Policy 33(1): 29-38.

Bendell, J., I. Doyle and E. Irwin (2009) 'World Review', Journal of Corporate Citizenship 36(4): 7-20.

Bassett, T.J. (2010) 'Slim Pickings: Fairtrade Cotton in West Africa', Geoforum 41(1): 4455.

Bezençon, V. (2011) 'Producers and the Fair Trade Distribution Systems: What are the Benefits and Problems?' Sustainable Development 19(1): 60-70.

Bezençon, V. and S. Blili (2011) 'Segmenting the Market through the Determinants of Involvement: The Case of Fair Trade', Psychology and Marketing 28(7): 682-708.

Bleischwitz, R., Dittrich, M. and C. Pierdicca (2012) 'Coltan from Central Africa, International Trade and Implications for Any Certification', Resources Policy 37(1): 19- 29.

Chavaz, J. (2008) Fair Trade and Corporate Social Responsibility - Convergence or Divergence? The Case of the Cocoa Business. Master Thesis, Institute for Environmental Decisions, ETH Zurich, Switzerland.

Cross, J., S. van der Wal and E. de Haan (2010) Rough Cut: Sustainability Issues in the Coloured Gemstone Industry. SOMO, Amsterdam.

Elder, S.D., Zerriffi, H., Le Billon, P. (2012) 'Effects of Fair Trade Certification on Social Capital: The Case of Rwandan Coffee Production', World Development 40(11): 2355-67.

Goodman, M.K. (2004) 'Reading Fair Trade: Political Ecological Imaginary and the Moral Economy of Fair Trade Foods', Political Geography 23(7): 891-915.

Griffiths, P. (2012) 'Ethical Objections to Fairtrade', Journal of Business Ethics 105(3): 35773.

Haufler, V. (2009) 'The Kimberley Process Certification Scheme: An Innovation in global Governance and Conflict Prevention', Journal of Business Ethics 89(4): 403-16.

Hilson, G. (2008) "Fair Trade Gold": Antecedents, Prospects and Challenges'. Geoforum 39(1): 386-400. 
Hilson, G. and S. Pardie (2006) 'Mercury: An Agent of Poverty in Ghana's Small-scale Gold Mining Industry?' Resources Policy 31(2): 106- 16.

Hira, A. and J. Ferrie (2006) 'Fair Trade: Three Key Challenges for Reaching the Mainstream', Journal of Business Ethics 63(2): 107-8.

Howard, P.H. and P. Allen (2008) 'Consumer Willingness to Pay for Domestic "Fair Trade": Evidence from the United States', Renewable Agriculture and Food Systems 23(3): 235-42.

International Monetary Fund (IMF) (2007) Malawi Growth and Development Strategy: From Poverty to Prosperity 2006- 2011. International Monetary Fund, Washington DC.

Kamlongera, P (2011) 'Making the Poor "Poorer" or Alleviating Poverty? Artisanal Mining Livelihoods in Rural Malawi', Journal of International Development 23(8): 1128-39.

Khamis, N. (2009) An Examination of Ethical Mineral Trading Initiatives: the Role of Knowledge Partnerships for Learning and Innovation. IDRC, Ottawa.

Levi, M. and A. Linton (2003) 'Fair Trade: A Cup at a Time?' Politics and Society 31(3): 407-32.

Loureiro, M.L and J. Lotade (2005) 'Do fair trade and eco-labels in coffee wake up the consumer conscience?' Ecological Economics 53(1): 129-38.

Luetchford, P. (2007) Hidden Hands in Fair Trade: Nicaraguan Migrants and the Labour Process in the Costa Rican Coffee Harvest. Sussex Migration Working Paper No. 44, Institute of Development Studies, University of Sussex, UK.

Maconachie, R. and T. Binns (2007) "Farming Miners"” or "'Mining Farmers"”?: Diamond Mining and Rural Development in Post-conflict Sierra Leone', Journal of Rural Studies 23: 367-80.

Marston, A. (2013) 'Justice for all? Material and Semiotic Impacts of Fair Trade Craft Certification', Geoforum 44(1): 162-69.

Mohan, S. (2009) 'Fair Trade and Corporate Social Responsibility', Economic Affairs 29(4): $22-28$.

Murray, D.L., Raynolds, L.T. and P.L. Taylor (2006) 'The Future of Fair Trade Coffee: Dilemmas Facing Latin America's Small-scale Producers', Development in Practice 16(2): 179-92.

Organization for Economic Cooperation and Development (OECD) (2010) 'Due Diligence Guidance for Responsible Supply Chains of Minerals from Conflict-Affected and High-Risk Areas'. Paris: OECD.

Perks, R. (2011) "“Can I Go?" Exiting the Artisanal Mining Sector in the Democratic Republic of Congo', Journal of International Development 23(8): 1115-27. 
Raynolds, L.T. (2002) 'Consumer/producer Links in Fair Trade Coffee Networks', Sociologia Ruralis 42(4): 404-24.

Schroeder, R.A. (2010) 'Tanzanite as Conflict Gem: Certifying a Secure Commodity Chain in Tanzania', Geoforum 41(1): 56- 65.

Shor, R. and R. Weldon (2009) 'Ruby and Sapphire Production and Distribution: A Quarter Century of Change', Gems and Gemology 45(4): 236-59.

Shor, R. and R. Weldon (2010) 'an era of sweeping change in diamond and colored stone Production and Markets’, Gems and Gemology 46(3): 166- 187.

Smillie, I. (2012) 'Blood Diamonds, Non-state Actors and Development: The Kimberley Process and Beyond', in D. Reed et al. (eds) Business Regulation and Non-State Actors: Whose Standards? Whose development?, pp. 213-24. London: Routledge.

Tallontire, A. (2002) 'Challenges Facing Fair Trade: Which Way Now?', Small Enterprise Development 13(3): 12-24.

Walton, A. (2010) 'What is Fair Trade?' Third World Quarterly 31(3): 431-47.

Wilson, B.R. (2010) 'Indebted to Fair Trade? Coffee and Crisis in Nicaragua', Geoforum 41(1): 74-83.

World Bank (2009) 'Malawi Mineral Sector Review'. Report No. 50160-MW. Washington, DC: World Bank.

Young, W. and K. Utting (2005) 'Fair Trade, Business and Sustainable Development', Sustainable Development 13(3): 139-42.

Gavin Hilson is Chair of Sustainability in Business at The Surrey Business School, University of Surrey, Guildford, GU2 7HX, United Kingdom. Professor Hilson carries out research on the environmental and interrelated social dimensions of small-scale mining in sub-Saharan Africa and The Guianas. E-mail: g.m.hilson@surrey.ac.uk 